\title{
A SURVEY OF STUDENTS' PERFORMANCE ON THE PIANO: A CASE STUDY OF THE DEPARTMENT OF MUSIC, UNIVERSITY OF PORT HARCOURT
}

*David BOLAJI

\section{Abstract}

Piano playing is one of the major courses under applied music studies in all departments of music in Nigeria. This course is compulsory for all the students either as a major or minor instrument as the case maybe. However, scholars have carried out different studies on the challenges of music students. However, The percent age ratio and performance of the female students on the piano in comparison to the percentage ratio of the male students have not received adequate attention. This paper therefore, examined the percentage ratio and the performances of female students on the piano using the department of music, University of Port Harcourt as a case study. Structured Purposive research sampling procedure was used to administer questionnaires to selected students from different levels in the music degree programme_so as to ascertain the problem(s) that affects the percentage ratio difference between the male and female students on piano. In addition, interview method was also employed. Findings revealed that most female students have a wrong misconception about piano by seeing it as a difficult instrument to learn, while some also sees piano as instrument made for the male students only. Furthermore, lack of interest, laziness, and inadequate time for practice and, the unavailability of pianos also stand as major challenges generally to the learning of the instrument.

Keywords: Percentage ratio, Piano, Female students, Principal instrument

\section{Introduction}

The conceptual act of piano playing in Nigeria could be traced back to the coming of the European to Nigeria. The midl9th century

\footnotetext{
*David BOLAJI is of the Department of Music, University of Port Harcourt, Rivers State Email: erin4daviddyahoo.co.uk
} 
witnessed the introduction and establishment of Western musical idioms and musical instruments Nigeria. (Omojola, 1995). Furthermore, in his submission Omojola, (1997), submitted that a distinctive musical acculturation was established in Nigeria as a result of the introduction of the foreign religion together with its musical idioms which eventually dominates the mode of worship in Nigeria. Scholars like Okafor (2005) and Akpakpan (2006) respectively sulomitted that another historical antecedent that introduced piano playing in Nigeria is also traceable European trade activities. All of these antecedents est ablished the generic root of Western styles of music and practices in Nigeria.

In line with the above, Ogisi, (2007), stated that the introduction of art music in Lagos in the 1880s came along with the art of piano playing. This was seen as the result of the activities and relentless efforts of the ex-slaves who were at the limelight of stage performances in different concert halls in Lagos. Nevertheless, the evolution and art of piano playing in Nigeria educational institutions most especially departments of music, witnessed the introduction and the teaching of harmonium organ playing through the missionaries in the earliest Teachers Training Colleges Mission Schools and Colleges of Education. Over time, the teaching and playing of piano metamorphosed into a standardized course of study now known as applied music studies in virtually all the departments of music. Students training encompass all aspects of music, piano inclusive. However, the percentage ratio difference and performance of the female students on the piano in the Departments of Music, University of Port Harcourt, has proven to be a major deficiency to the holistic training of the female students in their course of studying music. Nevertheless, there is an urgent need to address the above issue of the percentage ratio of female students and their poor performance on the piano. Therefore, the purpose of this study is to investigate the reasons for poor female students performance and to suggest possible solutions to the identified challenges.

\section{Piano and its Evolution}

From inception, piano stands to be a major musical instrument that has contributed immensely to the development and growth of music in the Western world. Its uses cut across numerous forms and styles of musical genre. This is because of its wide intervallic range that could be found, seen and used in composing for all other instruments. Which means, piano serves as the bedrock for other musical instruments in terms of accompaniment as the case may be. Also, it sets to be the first string instrument under the strings family right from the inception of harpsichord. Although the act of plucking 
strings using the key was predominately found in harpsichord which serves as the popular and major musical instrument of the 17th century in the Western world. The piano was developed around the 17th century, starting with the invention of the harpsichord in $\{1700\}$ by "Bartolome de Francesco". Furthermore, 'dulcimer a string box' also came to the limelight and then the invention of clavichord was introduced to the strings family. Nevertheless, the clavichord eventually led to the invention of the pianoforte. (Dolge, 1972, and Ford, 1979)

\section{Applied Music and its Philosophy}

Among the diverse courses of study in music department, applied music course serves as the avenue for teaching and training music students on various musical instruments which piano stands as one. Though the conceptualized act of applied music sets to be a major and compulsory course in the Departments of Music, University of Port Harcourt, as part of their under graduate degree programme. Nonetheless, the structure and contents of the course exposed all music students to the art of learning all kinds of musical instruments of their choice within the stipulated period of years that is required in their programme. This mean that, the study of applied music cut across the undergraduate programme, while the objective(s) of the course is to train, develop and equip all music students in various kinds of musical instruments so as to acquire all the necessary skill(s) that is needed to meet the demand of the societies. Although, the mode and pattern of running this particular course varies in other Departments Music, depending on the curriculum contents of each department of music in Nigeria. Nevertheless, different kinds of musical instruments such as Violin, viola, cello, double bass, lead guit ar, bass guit ar, drums, saxophone, trumpet, clarinet, flute, tuba, euphonium, cornet, piano, trombone and voice just to mention but a few fall under the applied studies. Likewise, it is compulsory for each student to choose any musical instrument as his/her major or minor instrument in addition to piano. This signifies that, piano as an instrument will definitely serve as either a major or minor instrument for the entire students in the department of music. The learning of Piano during the course of studying music as either a major or minor instrument now depends on the choice of individual student. In the same vein, despite the equal level of privilege of choosing piano as either a major or minor instrument, it is now a re-occurrence decimal that 99\% of the female students do not offer piano as their principle instnument right from their entry point and of the same percentage ratio do have poor performances at the end of the programme. The master of piano requires intensive steady hours of practices alongside it techniques and styles. The deliberate 
and constant practice activities improve the performance skills of students that long to be outstanding pianist. In his submission, Ibude (2010) stated that the proficiency of any student on the piano depends and requires a constant active devotion and focus practice of such student on the piano. He further stated that the clear understanding and accurate application of basic rudiments of music is required from such student on piano, which will eventually lead the student to out \$anding performance (s). In the same vein, Turnder (1999) opined that the outstanding public performance (s) of any student on the piano depend on the objectives teaching and learning of the student during the process of practicing piano. This implies that the numbers of hours spent in the journey of teaching, learning and practices of piano will result to the effective ability and skillfulness of any student that pays all of these sacrifices. However, this specific attribute is required in the act of learning and playing different kinds of musical instruments generally, but the major focal point of this paper set to be on piano. Although, the effective teaching of the instructor (s) stand as guard to effective achievement which could be made by any piano student.

\section{Investigation}

In an attempt to give full details on the purpose of this study, a statistical and descriptive analyses that characterized and represent the current position of the percentage ratio of the female students offering piano as principle instrument and other statistical ratios are $\$$ ated below, using the Department of Music, University of Port Harcourt as case study. In order to achieve this, structured questionnaire was designed and administered to 56 female students who are running the B. A. degree programme from different levels of studies. (Years One to Four). Most of the respondents are female students in their third and fourth years of study. This is because having spent three and half sessions and two and half sessions in the programme, their responses on the questionnaire stands to be the true picture and the true representative of the factors and reasons behind the impending challenges of the percentage ratio and the poor performance of female students offering piano as principle instruments in the Department. In addition to this, an open ended structured interview was also carried out with some piano instructors and some female students in order to get firsthand information to buttress the findings obtained from the data analysis of the questionnaires. The questionnaire used for this research study was designed to investigate the level of interest of female students towards the learning of piano, the attitudinal character of female students towards piano as an instrument, the efficiency of instructional methods in teaching piano as an instrument, the 
accessibility of the students to the piano and as well as the impact of the adequate or inadequate availability of the musical instruments (piano) in the departments of music. The Table below shows the percentage reflection of the statistic ratio of each level from year one to farr.

\section{Analysis of Results}

\begin{tabular}{|c|c|c|c|c|c|c|}
\hline C lass Year & $\begin{array}{l}\text { Total } \\
\text { Number of } \\
\text { Female } \\
\text { Students }\end{array}$ & $\begin{array}{l}\text { Total } \\
\text { Number of } \\
\text { Mal } \\
\text { Students }\end{array}$ & $\begin{array}{l}\text { Total } \\
\text { Number in } \\
\text { Class }\end{array}$ & $\begin{array}{l}\text { Total } \\
\text { Number of } \\
\text { Mal } \\
\text { Students } \\
\text { offering } \\
\text { Piano as } \\
\text { Mapir } \\
\text { instrum ent }\end{array}$ & $\begin{array}{l}\text { Total } \\
\text { Number of } \\
\text { Female } \\
\text { Students } \\
\text { offering } \\
\text { Piano as } \\
\text { Major } \\
\text { instrum ent }\end{array}$ & $\%$ \\
\hline Yearo ne & 14 & 30 & 44 & 5 & 0 & $11.4 \%$ \\
\hline YearTwo & 7 & 16 & 23 & 2 & 0 & 8.7 \\
\hline YearThree & 16 & 14 & 30 & 4 & 0 & $13.3 \%$ \\
\hline YearFour & 19 & 15 & 34 & 3 & 0 & $8.8 \%$ \\
\hline
\end{tabular}

In view of the above submission, 50 (89.3\%) of the respondents agree to the facts that the male students are doing better on the piano than the female students. But 6 (10.7\%) of the respondents gave their view that male students are not doing better than the female students. To buttress the above submission and position of the respondents that disagreed with the fact that male students are not doing better than the female students on the piano; 54 (96.4\%) accepted that piano as an instrument is not made for the male students alone. Rather, it is a universal musical instrument which could and should be played by everybody. Nonetheless, 2 (3.6\%) submit that piano as an instrument is purposely designed for the male students alone. Looking into the age group of students undertaking music as a course of study, 91.3\% falls under the age of 18 and 26 years of age, while $8.7 \%$ are 27 years of age and above. Furthermore, the percentage ratio of male students studying music said to be $57.7 \%$ while that of the female is $42.3 \%$. Similarly, the research study carried out shows that about $99.9 \%$ of the female students did not offer music at the (SSCE) Senior Secondary School Certificate Level, while about (0.1\%) offered music as a subject at the junior secondary level (JSS 3) only. The above result reveals that, most of the female students in the department of music did not have preceding knowledge in music before finding themselves in the field of studying music as profession. 
As the result of this, they could not have had any preceding knowledge on the piano as an instrument as well. Likewise, 56\% of the students undertook the certificate or pre-degree programme a non NUC programme as the case maybe before gaining admission into the B.A programme. This to an extent serves as a good platform of understanding the basic fundamentals of music before the full commencement of the B. A. programme.

\section{Students Interest in Music}

The interest of most of the female students in the department of music is not to study music, but the study of other courses. But due to the difficulties encountered in gaining admission into their choice of study department, they eventually found themselves in department of music. According to Feberesima (2012), some of them (students) were transferred to the Department of music from other departments of their interest right from their certificate programme as the result of them not meeting up with the cutoff mark required by such departments. Similarly, Enakpone (2013) and Nsofor (2013) buttressed the above submission that the mode of their admission into the Department of music was not on their individualistic interest as the case maybe, but as a result of them not scoring the required cutoff mark of their various departments of interest. This singular approach of recruiting students into the department of music has made the mind-set of most students especially the female students to be divided from the very beginning. Also, this act stands as the bedrock and foundation to which every other aspect of their stuoly is being built on. As the result of this, quite a number of the female students have an abused mind towards music before the cormencement of the B. A. programme. Nevertheless, the research carried out reveals that 98\% of the female students never wanted to study music but eventually found themselves in the department of music. Although, most times after the certificate programme, about 50\% of them came to fall in love with the profession and eventually decided to continue with the programme at the B.A level. Similarly, the statistic results of the percent age ratio and poor performances of female students on the piano reveals that 57.1\% of the female students accepted the fact that piano is not their best musical instrument. But 41.1\% opted for piano as their best instrument. only 1 respondent falls under the category of an indecisiveness which set to be of (1.8\%) of the sum total number of the respondents. (69.6\%) of the respondents find the leaming and playing of piano difficult. While $30.4 \%$ of the respondents agreed that they found the learning and playing of piano easy. (66.1\%) of the female students opted that if they are given a choice to choose, they will never offer piano 
throughout their course and years of studies. (33.9\%) of the female students responded that their poor performance and the bad percentage ratio of female students on the piano is the result of their lack of interest in the instrument. But (60.7\%) of the respondents opted that their inefficiency is not as the result of their interest.

\begin{tabular}{|c|c|c|}
\hline \multicolumn{3}{|c|}{ Q uestion $1: P$ iano is $\mathrm{m} y$ best instrum ent in the departm entofm usic } \\
\hline & $\begin{array}{ll}\text { Num ber } & \text { of } \\
\text { Respondents } & \end{array}$ & Percentage of respondents \\
\hline Yes & 32 & $76.4 \%$ \\
\hline No & 23 & $21.5 \%$ \\
\hline Indecisìeness & 1 & $2.1 \%$ \\
\hline $\begin{array}{l}\text { Total } \\
\text { N um berp ercentage }\end{array}$ & 56 & $100 \%$ \\
\hline \multicolumn{3}{|c|}{ Q uestion $2:$ Ido find iteasy to play the piano despite the com plexity of the instrum ent. } \\
\hline Yes & 39 & $69.6 \%$ \\
\hline No & 17 & $30.4 \%$ \\
\hline $\begin{array}{l}\text { Total } \\
\text { N um berp ercentage }\end{array}$ & 56 & 100 \\
\hline \multicolumn{3}{|c|}{ Q uestion 3: If Ihave m y way, Iw illnotofferpiano as a course underapplied m usic. } \\
\hline & $\begin{array}{c}\text { Num berof } \\
\text { Respondents }\end{array}$ & Percentage ofRespondents \\
\hline Yes & 37 & $66.1 \%$ \\
\hline No & 19 & 32.1 \\
\hline Indecisìeness & 1 & $1.8 \%$ \\
\hline $\begin{array}{l}\text { Total } \\
\text { N um berp ercentage }\end{array}$ & 56 & $100 \%$ \\
\hline
\end{tabular}

Q uestion 4:M y inefficincy on the pino is as a resultof lack of intereston $m$ y part.

\begin{tabular}{|l|c|c|}
\hline & $\begin{array}{c}\text { Num berof } \\
\text { Respondents }\end{array}$ & Percentage ofRespondents \\
\hline Yes & 34 & $60.7 \%$ \\
\hline No & 19 & $33.9 \%$ \\
\hline Indecision & 3 & $5.4 \%$ \\
\hline $\begin{array}{l}\text { Total Num ber/ } \\
\text { Percentage }\end{array}$ & 56 & 100 \\
\hline
\end{tabular}




\section{Inadequacy of Pianos}

The inadequacy of piano in the departments of music stands as one of the major factors that is contributing to the poor performance of the female students on the piano. Studies carried out revealed that the numbers of digital pianos available in the departments are very few compared to the number of students. Although $50 \%$ of the respondents disagreed that the inadequacy of this instrument in their departments contributed to their inefficiency on it. These respondents blamed the inefficiency on the poor methods of teaching, insufficient time to practice, heavy workload in terms of the number of courses they are of fering in a session, etc. However, 46.4\% accepted that the inadequacy of pianos contributed to their inefficiency on the instrument. The further stated that if there are enough pianos in the department, the issue of poor performance on the piano among female students would not have been an issue. Rather, it would have been on a different platform as it may affect the students and their academics. Likewise, only 2 of the respondents (3.6\%) were undecided on the issue of the inadequacy of the piano. To this ef fect, the availability of piano will surely improve the performance of the female students coupled with the hour(s) of practice that each student ought to spend every day with their instructor(s) through a proper scheduled timetable roster. This would have helped the art of playing piano not just for the female students but that of the male students would also improved beyond its present state.

\begin{tabular}{|l|c|c|}
\hline Question 6: In adequacy ofpiano in m y departm entcontrbuted to m y inefficincy on the pino. \\
\hline $\begin{array}{c}\text { Num berof } \\
\text { Respondents }\end{array}$ & Percentage ofRespondents \\
\hline Yes & 26 & $46.4 \%$ \\
\hline No & 28 & $50 \%$ \\
\hline Indecisiveness & 2 & $3.6 \%$ \\
\hline $\begin{array}{l}\text { Total Num ber } \\
\text { Percentage }\end{array}$ & 56 & 100 \\
\hline
\end{tabular}

\section{Poor Method(s) of teaching}

As shown in the Table below, 33 (58.9\%) of the respondents stated that the poor percentage ratio and poor performances of the female students on the piano is the result of the poor methods of teaching of the various piano instructors. This means the issue of learning usually does not occur in most of the piano classes which could be as the result of the wrong pattem of delivering of the lesson by the instructors. Although about 22 (39.3\%) of the respondents disagreed that the poor methods of teaching by the instructors led to 
their inefficiency on the piano, rather, they attribute their poor performance to others factors. However, only 1 (1.8\%) of the respondents was indecisiveness on this issue.

\begin{tabular}{|l|c|c|}
\hline \multicolumn{2}{|c|}{$\begin{array}{c}\text { Q uestion 7:P oorm ethod (s) ofteaching ofpino by instructors ld to m y inefficiency on the } \\
\text { pino. }\end{array}$} \\
\hline $\begin{array}{c}\text { Num berof } \\
\text { Respondents }\end{array}$ & Percentage ofRespondents \\
\hline Yes & 33 & $58.9 \%$ \\
\hline No & 22 & $39.3 \%$ \\
\hline Indecisiveness & 1 & $1.8 \%$ \\
\hline $\begin{array}{l}\text { Total Num berl } \\
\text { Percentage }\end{array}$ & 56 & 100 \\
\hline
\end{tabular}

In view of the forgoing, despite the poor percentage ratio and poor performance of the female students on the piano, it is worthy of note to be mentioned that the instrument still has a strong positive position in the hearts and hands of the female students in the department of music. 46 (82.1\%) of the respondents gave a positive position that piano should not be scraped out of the department of music while 10 (17.9\%) of the respondents stated their position by supporting the idea of scraping out piano among the lists of musical instruments in the department of music. The above result proves that there a major problem on the issue of learning and teaching of piano in the departments of music and not the issue of seeing the instrument as a complex musical instrument. Similarly, of the total number of the respondents, $54(96.4 \%)$ believed and stated clearly that they can be one of the best female pianist in the world if they devote more time to practice of piano. Which means the undertone problem facing them on the piano could be associated with the negligence on their part in terms of not putting enough hours to practice. But $2(2.6 \%)$ of the total respondents were not optimistic on being one of the best female pianist in the world even if they devoted enough time to practice. To buttress the positive position of most female students towards piano as an instrument in the department of music, findings revealed that 48 (85.7\%) of the respondents never disliked piano as an instrument. This finding negates the general saying and belief that "the female students in the departments of music dislike piano as an instrument". However, 8 (14.3\%) of the respondents agree to the fact that, they dislike piano as an instrument. All of the above findings were represented on the table below. 


\begin{tabular}{|c|c|c|}
\hline \multicolumn{3}{|c|}{$\begin{array}{l}\text { Q uestion 8:P ano study should be scrapped out of the listofm usicalinstrum ents in the } \\
\text { departm ent. }\end{array}$} \\
\hline & $\begin{array}{l}\text { Num berof } \\
\text { Respondents }\end{array}$ & Percentage ofRespondents \\
\hline Yes & 10 & $17.9 \%$ \\
\hline No & 46 & $82.1 \%$ \\
\hline \begin{tabular}{ll|} 
Total Number/ \\
Percentage
\end{tabular} & 56 & 100 \\
\hline \multicolumn{3}{|c|}{$\begin{array}{c}\text { Q uestion 9: Ican be one of the best fem al pianists in the world if Ican create m ore tin e o } \\
\text { piano practice. }\end{array}$} \\
\hline & $\begin{array}{c}\text { Numberof } \\
\text { Respondents }\end{array}$ & Percentage ofRespondents \\
\hline Yes & 54 & $96.4 \%$ \\
\hline No & 2 & $3.6 \%$ \\
\hline \begin{tabular}{ll|} 
Total Number/ \\
Percentage
\end{tabular} & 56 & 100 \\
\hline \multicolumn{3}{|c|}{ Q uestion 10: Iw ould have bved to be a fem al panistbut Idislike the instrum ent } \\
\hline & $\begin{array}{c}\text { Num berof } \\
\text { Respondents }\end{array}$ & Percentage ofRespondents \\
\hline Yes & 8 & $14.3 \%$ \\
\hline No & 48 & $85.7 \%$ \\
\hline \begin{tabular}{ll|} 
Total Number/ \\
Percentage
\end{tabular} & 56 & 100 \\
\hline
\end{tabular}

Putting into consideration the poor percentage ratio of the female students offering piano as principle instrument in comparison with that of the male students, a clear difference reflected in the two gender ratio representation. Finding reveals that two or more of male students out of the total number of the general students in each level of the classes from year one to four offer piano as major instrument while none of the female students could be said to be a piano major student. Nevertheless, despite the fact that both genders received teaching from the same instructors as the case may be, the outcome of this research reveals that the male students are doing better on the piano than the female students.

Speaking on the poor percentage ratio and the performance of the female students on the piano, most of the female students identified wrong and poor tutelage and lack of mentorship from their instructors as the major undertone factor to their problem. This means that if they have better tutelage from their instructors, there is every possibility that they will do better than the male students. Findings noted that 54 (96.4\%) agreed with this submission while 2 (3.6\%) stood on the ground of indecisiveness. To this finding, there is no single female that disagreed with the above fact and submission. 


\begin{tabular}{|c|c|c|}
\hline Q uestion 11:The m al s & ts are doing be & e students on the pino in $m y$ \\
\hline & $\begin{array}{l}\text { Numberof } \\
\text { Respondents }\end{array}$ & Percentage ofRespondents \\
\hline Yes & 50 & $89.3 \%$ \\
\hline No & 6 & $10.7 \%$ \\
\hline $\begin{array}{l}\text { Total Numberl } \\
\text { Percentage }\end{array}$ & 56 & 100 \\
\hline Question & ino as an instr & forthe $m$ al students only. \\
\hline & $\begin{array}{l}\text { Num berof } \\
\text { Respondents }\end{array}$ & Percentage ofRespondents \\
\hline Yes & 2 & $3.6 \%$ \\
\hline No & 54 & $96.4 \%$ \\
\hline $\begin{array}{ll}\text { Total } & \text { Number/ } \\
\text { Percentage } & \\
\end{array}$ & 56 & 100 \\
\hline Q uestion $10: \mathrm{Iw}$ & ay betterthan $m$ & piano if Thave a propertutela \\
\hline & $\begin{array}{l}\text { Numberof } \\
\text { Respondents }\end{array}$ & Percentage ofRespondents \\
\hline Yes & 54 & $96.4 \%$ \\
\hline Indecisiveness & 2 & $3.6 \%$ \\
\hline $\begin{array}{ll}\text { Total } & \text { Num berl } \\
\text { Percentage } & \end{array}$ & 56 & 100 \\
\hline
\end{tabular}

Interest and Devoted time to Practice

The statistic findings shows that most female students actually devote less time to piano practices, while the male students find more time to practice and even go beyond the schedule examination pieces given to them. To this end, the opinion of the 41 (73.2\%) respondents agree with the above submission while 15 (26.8\%) disagrees with the submission. In their own opinion, the poor percentage ratio of the female students on the piano have nothing to do with the lack of interest on the part of the female students but having to do with other factors that affects their performances. But the high level of interest displayed towards piano by the male students has made most of the male students to have special interest for the instrument. Apart from this fact, some of the male students do create more time to practicing of piano as it is discovered from the result of this study that 45 (80.4\%) of the male students devotes more time for rehearsal on the piano than the female students. While 11 (19.6\%) of the respondents disagree with the said submission of the male students giving more time than the female students to the piano. 


\begin{tabular}{|l|c|c|}
\hline \multicolumn{2}{|c|}{ Question 14:Them ale students have m ore interest in pino than the fem ale students } \\
\hline & $\begin{array}{c}\text { Numberof } \\
\text { Respondents }\end{array}$ & Percentage ofRespondents \\
\hline Yes & 41 & $732 \%$ \\
\hline No Number & 15 & $26.8 \%$ \\
\hline $\begin{array}{l}\text { Total } \\
\text { Percentage }\end{array}$ & 56 & 100 \\
\hline \multicolumn{2}{|c|}{ Question 15:The mab students do create m ore tine in practicing pino. } \\
\hline \multicolumn{2}{|c|}{$\begin{array}{c}\text { Numberof } \\
\text { Respondents }\end{array}$} & Percentage ofRespondents \\
\hline Yes & 45 & $80.4 \%$ \\
\hline No & 11 & $19.6 \%$ \\
\hline $\begin{array}{l}\text { Total Number } \\
\text { Percentage }\end{array}$ & 56 & 100 \\
\hline
\end{tabular}

\section{Impact of the Instructor Method(s) of Teaching}

The impact of the instructor(s) teaching in the learning course of every student could either be negative or positive. The impact is said to be positive when learning had taken place. That is when there is proper communication and transfer of knowledge from the teacher to the student $(\mathrm{s})$. This simply means that the place of understanding of the students cannot be downgraded because the effect and outcome of every teaching can be evaluated through the student's understanding and the ability to recap what was thought by the teacher or instructor. In this study, the perceptive views of the respondents towards the effective impact of their piano instructors were reviewed and classified under five (5) categories which are: extremely effective, very effective, moderately effective, slightly effective and not effective. The students' perception of how effective their instructors' methods of teaching is, was placed on different platform based on the rating of individual students. However, 4 (7.1\%) rated their instructors teaching impact to be extremely effective while 10 (17.9) of the respondents also rated their instructors methods of teaching to be very effective. The highest rating of the instructor's teaching methods falls under moderately effective. 25 (44.6\%) acclaimed the teaching of their instructors to be under this category. 11 (19.6\%) of the respondents agreed that the effect of their instructors teaching does not go beyond slightly effective while 4 (7.1\%) also rated them to be not effective. Only 2 (3.5\%) of the respondents could not place their instructor's effective teaching on any of the above category which rendered them as an indecisive. Table below represent the general overview of the effective teaching of the instructors' methods. 


\begin{tabular}{|l|l|l|}
\hline $\begin{array}{l}\text { Effectiveness of instructor(s) } \\
\text { teaching }\end{array}$ & Num berofRespondents & $\%$ \\
\hline Extrem efy effective & 4 & $7.1 \%$ \\
\hline Very effective & 10 & $17.9 \%$ \\
\hline Moderately effective & 25 & $44.6 \%$ \\
\hline Slighty effective & 11 & $19.6 \%$ \\
\hline Notalleffective & 4 & $7.1 \%$ \\
\hline Undecided & 2 & $3.6 \%$ \\
\hline Total & 56 & 100 \\
\hline
\end{tabular}

\section{In-depth interview with piano instructors}

In an attempt to justify the findings of this study, an open ended interview was carried out with five (5) piano instructors who are also members of academic staff of the department. Direct questions were asked during the interviews which are of necessity to pinpoint the basic factors that led to the poor percentage ratio and poor performances of female students on the piano. In the view of the instructors, lack of interest on the part of the female students towards piano serves as a major factor affecting the percentage ratio and poor performances of this gender. Basically, 98\% of the piano instructors in the department suggested that most of the female students do not have interest in leaming the piano. This is because quite a number of them see the instrument as a highly technical instrument which is mainly made and designed for the male students only. The above factors among other factors as stated by the instructors brought a huge percentage ratio different between the male and female students in the learning and playing of the piano in the department. However, research have stated it that interest serves as the predominant factor most especially for the young students in selecting, pursuing and determining the process of their learning a particular course/task in preference to others. This simply means that, the individual interest of a student propels and facilitates the cognitive process of achieving and gaining knowledge in a specific learning process. Similarly, this suggests that interest st and as a strong phenomenon that restrains any identified or un-identified factor(s) that may stand as barrier on the part of the learning process of any student. Thus, it's a spontaneous attribute that comes from within an individual student which instigates and redirects the positive consciousness of achieving a particular course/task. (Hidi, 2016 and Bolaji, 2016) .

Nevertheless, few female students were identified which were about $2 \%$ of the overall percentage of the female students with strong and high level of interest on the piano. Likewise, it is the notion of the 
instructors that certain students are doing well in their piano playing, even though the number is insignificant in comparison to the overall number of the female students in the department. Furthermore, the instructors identified unserious attitude, laziness and lack of quest for knowledge on piano as part of the major factors that brought about the said predicament of the female students on the piano in the Department. Likewise, they perceived a nonchalant attitude towards the learning of piano from the female students in comparison to the positive attitude that most male students portray towards the same instrument. The instructors opine that, the attitudinal factor has led to a strong laziness on the part of the female students. In view of this, it is the opinion of the instructors that quite a number of these students do create time for the practicing of piano except only during the applied music examinations which means most of the female students' only practiced piano in order to pass their applied music in piano and not for the pursuit of knowledge as the case should be. Even though learning to pass is paramount in the academic pursuit of every student but the place of knowledge stands and goes beyond the four walls of the class room. Practicing just to pass piano or other instruments/ courses shouldn't be the aim, but how to meet the demand of the society after school. The first hand information given by the instructors revealed that the inadequacy of piano in the department only has little negative impact on the leaming of the piano as an instrument. In their sulomission, they affimmed that even with few available pianos in the department, some students are still doing great in their learning and playing of the instrument. However, they acknowledge that the availability of more piano in the department will certainly aid more improvement in the teaching and learning of the instrument generally.

\section{Conclusion and Recommendations}

The teaching and learning of piano has been identified as a compulsory course under the applied music in the higher learning of institutions where music is being offered in Nigeria with reference to the Department of Music, University of Port Harcourt. This aspect of applied music could be major or minor based on the interest of individual student. However, among the diverse issues af fecting the holistic performance of the students in the Department of Music, University of Port Harcourt, the poor percentage ratio and performances of female students on the piano has been identified as the focal point of this study. In order to address the present challenges that led to this predicament, the following were identified as the main factor which includes: wrong method of admission, lack of interest on the part of the female students, attitudinal issues towards piano, insufficient time 
of practicing piano, poor method(s) of teaching, lack of tutelage/ mentorship, inadequate piano in the department, etc. In view of the aforementioned problems identified in this study, the following recommendations are strongly propounded. The entry mode of students into the department of music should be strictly on merit in music. This means student should be admitted into the department of music if such student has the requirements and applied for music as course of study. Furthermore, any candidate that will be admitted into the music programme should definitely have interest in studying music as a profession. The mode of teaching piano as an instrument needs to be re-addressed. In-view of this, giving the students their applied music pieces in piano without proper tutelage procedure should stop. This is because for any female student to succeed in piano playing, there must be a proper time and adequate teaching stages between the instructor and the student. Also, there is an urgent need to increase the numbers of piano in the department if truly a positive and better result want $s$ to be achieved. To this ef fect, the University management needs to equip the department of music with enough and necessary piano required by the department. The art of playing piano just to pass applied music should stop. In regards to this, standardized choice of pieces should be collated for each level while a strict mode of standard in terms of strength and ability in playing piano should be put in place for certain and specific stages before the examination period. This should be for all the students and not just for the female students alone. Failure of any students to attain any of the set stages and standard before the examination day means such a student will automatically not qualify for the piano exam. Through this measure, all the lazy female students and those amidst the male students will surely sit up in their leaming and playing of piano. Also, this will cert ainly help all the instructors to carry out their responsibilities properly as require. And finally, it will improve the holistic percent age ratio and the performance ability of the female students and the entire students of the department on the piano.

\section{References}

Akpakpan, J. (2006) . Neo-Nigeria art composition: The case of Ekanem. Awka Journal of Research in Music and the Related Arts 3 (1) , 218-238.

Dolge, A. (1972). Pianos and their makers: A comprehensive history of the development of the piano. New York: Dover Publication, Inc. 
Ford, C. (1979). Making musical instruments: Strings and keyboard. New York: Pantheon Books.

Omojola, B. (1995). Nigeria art music. Ibadan: Institute of Franchaise De Recherche De Afrique (IFRA).

- (1997) . Composition styles and national identity. In B. Omojola (ed.) Music and social dynamics in Nigeria. Ilorin: Department of Performing Arts, University of Tlorin.

Nwadukwe, C. (1995). Junior secondary school music education: The way forward. Paper presented at the 3rd National Conference on Nigerian Music at Obafemi Awolowo University, Tle-Ife.

Ogisi, A.A. (2007). Nigeria composers and the search for national identity: Of the sonic and structural. Akwa Journal of Research in Music and the Ants 4 (1), 134-145.

Okafor, R. C. (1988). Focus on music education in Nigeria. Intemational Journal of Music Education, 12, 9-17.

- (2005). Music in Nigerian society. Enugu: New Generation Book Ltd.

Ioude, O. (2011). The adult pianist as a music educator: The Nigeria Baptist theological seminary (NBTS) Ogbomosho experience. Nigerian Music Review, 11\&12 (1), 43-51.

\section{Interviews}

Feberesima, G. Personal interview, 15th, September 2012, Port Harcourt, Rivers State.

Enakpona, E. Personal interview, 11th, June 2013, Port Harcourt, Rivers State.

Nsofor, C. Personal interview 15th, June 2013, Port Harcourt, Rivers S tate. 